\title{
STUDY CASE OF AIR-MASS MODIFICATION OVER POLAND AND ROMANIA OBSERVED BY THE MEANS OF MULTIWAVELENGTH RAMAN DEPOLARIZATION LIDARS
}

\author{
Montserrat Costa-Surós ${ }^{1}$, Lucja Janicka ${ }^{1}$, Iwona S. Stachlewska ${ }^{1 *}$, Anca Nemuc ${ }^{2}$, Camelia Talianu ${ }^{2}$, \\ Birgit Heese $^{3}$, Ronny Engelmann ${ }^{3}$ \\ ${ }^{1}$ Institute of Geophysics, Faculty of Physics, University of Warsaw, Warsaw 02-093, Poland, \\ *Email: iwona.stachlewska@igf.fuw.edu.pl \\ ${ }^{2}$ National Institute of $R \& D$ for Optoelectronics Romania (INOE), Magurele, Romania \\ ${ }^{3}$ Institute for Tropospheric Research (TROPOS), Leipzig, Germany
}

\begin{abstract}
An air-mass modification, on its way from Poland to Romania, observed between 19-21 July 2014 is discussed. The air-mass was investigated using data of two multi-wavelength lidars capable of performing regular elastic, depolarization and Raman measurements in Warsaw, Poland, and in Magurele, Romania. The analysis was focused on evaluating optical properties of aerosol in order to search for similarities and differences in the vertical profiles describing the atmospheric layers above the two stations within given period.
\end{abstract}

\section{INTRODUCTION}

There are a few multi-wavelengths lidar systems in Eastern Europe. According to EARLINET [1] there are lidar stations in Magurele (Romania), Minsk (Belarus), Belsk (Poland). The second Polish lidar site in Warsaw only recently joined the EARLINET lidar network. The low number of remote sensing stations is one of the reasons why little studies of air-mass modification have been done over Eastern Europe, in comparison with western part of Europe.

The air-mass modification studies are important to assess how particular modification influences boundary layer composition and dynamics, clouds properties, radiative transfer, and its effect on weather and regional climate. Therefore, we frequently search in the available lidar data sets for special events occurring over the Eastern Europe, e.g. biomass burning from forest fires, desert dust advection, episodes of cold air masses descending from Arctic. This resulted in a few case studies using lidar data from Warsaw and
Magurele, e.g. optical properties of long-range transported volcanic ash during Eyjafjallajökull eruption in April 2010 were analyzed over Poland and Romania [2]. A recent study of the Canadian forest fire event observed over Warsaw during July 2013 revealed another air-mass path transporting mineral dust particles form Sahara [3]. Here we discuss a case of an air-mass flow from Poland to Romania, over the NW-SE transect that allows for assessing the role of Carpathian Mountains in this air-mass modification.

\section{METHODOLOGY}

The measurements, taken by two multiwavelength Raman lidars, one based at the Radiative Transfer Laboratory (RT-Lab) of the Institute of Geophysics, Faculty of Physics, University of Warsaw (Poland) and the second installed at the RADO site of the National Institute of R\&D for Optoelectronics (INOE) in Magurele (Romania), have been evaluated. The study is complemented with meteorological data collected at two other sites: the SolarAOT in Strzyżów (Poland) equipped, among other instrumentation, with the AERONET photometer and the CHM15k ceilometer, and the Observatory of Cluj (Romania). Along with these data we used information obtained from satellite imagery to describe the local and regional meteorological situation development and to further characterize the aerosols properties. As the four mentioned above stations are located along a north-west to south-east transect, the main objective of the study was to evaluate properties of the aerosol 
transported by the air flow over Poland, Slovakia, further to Romania.

The RT-Lab site at Warsaw $\left(52.21^{\circ} \mathrm{N}, 20.98^{\circ} \mathrm{E}\right.$, $96 \mathrm{~m}$ a.s.l.) joined the EARLINET in 2015, contributing to the network activities with the 8channel $(2 \alpha+3 \beta+2 \delta+\mathrm{VW})$ Aerosol-Depolarization -Raman (ADR) lidar, that is a NeXT generation Polly ${ }^{\mathbf{X T}}$ system developed in a scientific cooperation with TROPOS, Germany [4]. Moreover, the RT-Lab and the SolarAOT sites are part of the Poland-AOD Consortium network (http://www.polandaod.pl).

The RADO site at Magurele $\left(44.05^{\circ} \mathrm{N}, 26.03^{\circ} \mathrm{E}\right.$, $93 \mathrm{~m}$ a.s.l.) near Bucharest, equipped among other instrumentation with the 7-channel $(2 \alpha+3 \beta+1 \delta+\mathrm{WV})$ Raman Lidar (RALi), that was developed by RAYMETRICS, Greece, is recognized as one of advanced EARLINET stations since 2007 [1]. The RADO is also an AERONET site. A list of differences in the detection scheme of the RALi lidar with respect to the ADR lidar are given in Table 1.

\begin{tabular}{|c|c|c|c|c|}
\hline \multirow{2}{*}{} & \multicolumn{2}{|c|}{$\begin{array}{c}\text { Detected } \\
\text { Wavelength } \\
{[\mathrm{nm}]}\end{array}$} & \multicolumn{2}{|c|}{ Detection type } \\
\cline { 2 - 4 } & $\begin{array}{c}\text { RALi } \\
\text { lidar }\end{array}$ & $\begin{array}{c}\text { ADR } \\
\text { lidar }\end{array}$ & $\begin{array}{c}\text { RALi } \\
\text { lidar }\end{array}$ & $\begin{array}{c}\text { ADR } \\
\text { lidar }\end{array}$ \\
\hline \multirow{2}{*}{$\begin{array}{c}\text { Elastic } \\
\text { total }\end{array}$} & 1064 & $\begin{array}{c}1064 \\
355\end{array}$ & A & \\
\cline { 2 - 4 } & 355 & 532 & A \& PC & \\
\hline $\begin{array}{c}\text { Vibrational } \\
\text { Raman } \mathrm{N}_{2}\end{array}$ & 387 & $\begin{array}{c}607 \\
387\end{array}$ & A \& PC & \\
\cline { 1 - 3 } $\begin{array}{c}\text { Elastic } \\
\text { parallel }\end{array}$ & 532 & & A \& PC & \multirow{2}{*}{ PC } \\
\hline $\begin{array}{c}\text { Elastic cross- } \\
\text { parallel }\end{array}$ & 532 & 532 & A \& PC & \\
\hline Raman $\mathrm{H}_{2} \mathrm{O}$ & 408 & 407 & PC & \\
\hline
\end{tabular}

Table 1. Detection channels for the multi-wavelength lidars at the RADO in Magurele and the RT-Lab in Warsaw (A: analog, PC: photon counting).
In order to assess the evolution and modification of the air flow properties during the overpass over the two countries between 19-21 July 2014, the particle backscatter coefficient profiles at 355 , 532 and $1064 \mathrm{~nm}$ and the particle extinction profiles at 355 and $532 \mathrm{~nm}$ were obtained at both sites [5]. Also the calibrated depolarization profiles at $532 \mathrm{~nm}$ at RADO, as well as at 532 and $355 \mathrm{~nm}$ at RT-Lab were calculated [6]. If feasible, the retrieval of aerosol microphysical properties for found characteristic layers will follow, in a near future [7]. The ceilometer measurements at SolarAOT site were evaluated using routines by $[8,9,10]$ for retrieval of both aerosol content and $\mathrm{PBL} /$ cloud layers structure.

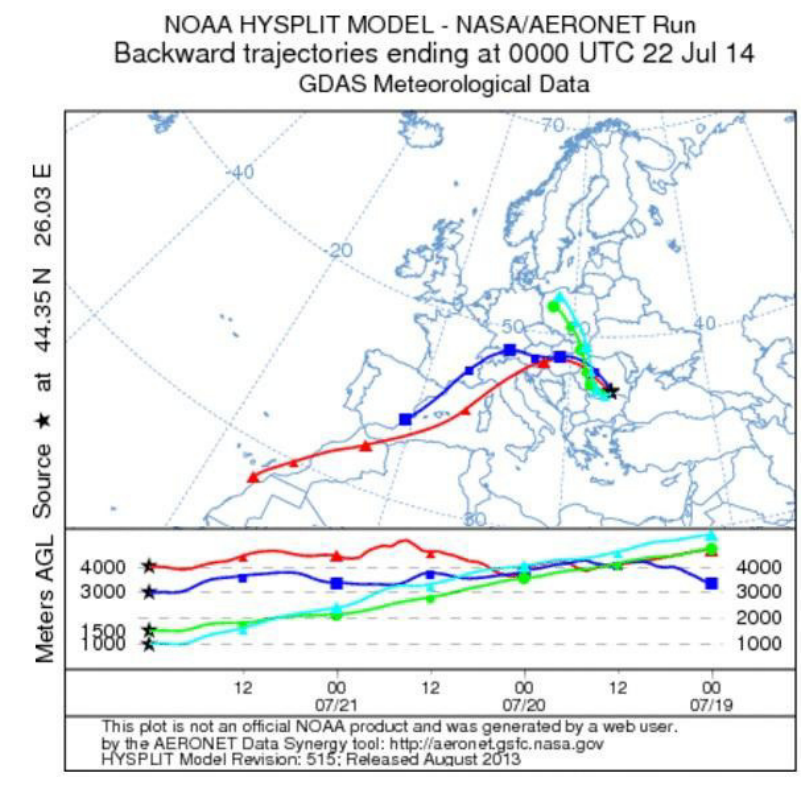

Figure 1. NOAA Hysplit backward trajectories ending at 00 UTC on $22^{\text {nd }}$ July 2014 in Magurele at 1, 1.5, 3 and $4 \mathrm{~km}$. Note that the lowermost air-masses crossed Poland on July $19^{\text {th }}, 2014$ and reached Romania on July $21^{\text {st }}$.

\section{RESULTS}

Accordingly to NOAA Hysplit 4-days backward trajectories (Fig.1), ending up at Magurele at 1, $1.5,3$ and $4 \mathrm{~km}$, during the identified period an air-mass (Fig.1, in green, magenta) that crossed Poland on July $19^{\text {th }}, 2014$ descended on the following day over the SolarAOT station in Strzyżów, then further over Cluj site in Romania, and ended up in Magurele on July $21^{\text {st }}, 2014$. The air-mass that ended at $3 \mathrm{~km}$ in Magurele 
(Fig.1, blue), originated in south-eastern coast of Spain in Europe. The air-mass that advected at 4 $\mathrm{km}$ over Magurele (Fig.1, red), came from the west coast of Morocco in Africa. Neither of the three identified air masses were mixed into each other as their paths were well separated in time and horizontal/vertical space.

At both sites the backscatter coefficient profiles at (Fig. 2) show distinctly layered structure in the atmosphere. Note that the profiles from Warsaw have resolution of $7.5 \mathrm{~m}$ and were smoothed using Savitzky-Golay filter, while the profiles from Magurele were smoothed with an adaptive smoothing filter and their effective resolution is linearly increasing from $7.5 \mathrm{~m}$ to $1500 \mathrm{~m}$.

Both lidars reveal multi-layer aerosol structures during this period. The lidar data from 21 to 22 UTC collected at RT-Lab on July $19^{\text {th }}, 2014$ show backscatter peaks roughly at $2 \mathrm{~km}$ and at $2.7 \mathrm{~km}$ for VIS and UV channels (Fig. 2, left). Additional layers are visible at about $3 \mathrm{~km}$ (only in VIS) and at $7.2 \mathrm{~km}$ (only in UV). Whereas, the lidar data at RADO on July $21^{\text {st }}, 2014$ reveals layered structure with peaks at roughly $2 \mathrm{~km}, 3.2 \mathrm{~km}$, and $4 \mathrm{~km}$ (Fig. 2, right).

Here we focus on two distinct air-masses, i.e. the air-mass from Africa that was directly advected at $4 \mathrm{~km}$ over Magurele, and the air-mass from over Poland, that reached Magurele at $1.5 \mathrm{~km}$. Not only the origin of these air-masses is different, they also have not been mixed and thus, one can study their properties depending on where they came from.

The latter air mass was likely modified by the Carpathian Mountains on its way, as it descended following the terrain between the two countries. The backscatter values at $1.5 \mathrm{~km}$ over Magurele are $1.4 \cdot 10^{-6}$ at $532 \mathrm{~nm}$ and $3.1 \cdot 10^{-6} \mathrm{~m}^{-1} \mathrm{sr}^{-1}$ at 355 $\mathrm{nm}$; while the same air-mass which was detected at about $3.5 \mathrm{~km}$ over Warsaw show backscatter coefficients of $5 \cdot 10^{-6}$ at $532 \mathrm{~nm}$ and $2.2 \cdot 10^{-6} \mathrm{~m}^{-1} \mathrm{sr}^{-}$ ${ }^{1}$ at $355 \mathrm{~nm}$. The linear depolarization ratio (not shown here) for the air-mass advected at an altitude of $1.5 \mathrm{~km}$ over Magurele on July $21^{\text {st }}$, 2014 is of about $5 \%$ at $532 \mathrm{~nm}$, while the same air-mass was at $3.5 \mathrm{~km}$ over Warsaw on July $19^{\text {th }}$, 2014 where it had only $1 \%$ at 532 and $2.4 \%$ at 355 $\mathrm{nm}$. Higher depolarization value of $9 \%$ at $355 \mathrm{~nm}$ was calculated at $8.5 \mathrm{~km}$ indicating Cirrus.
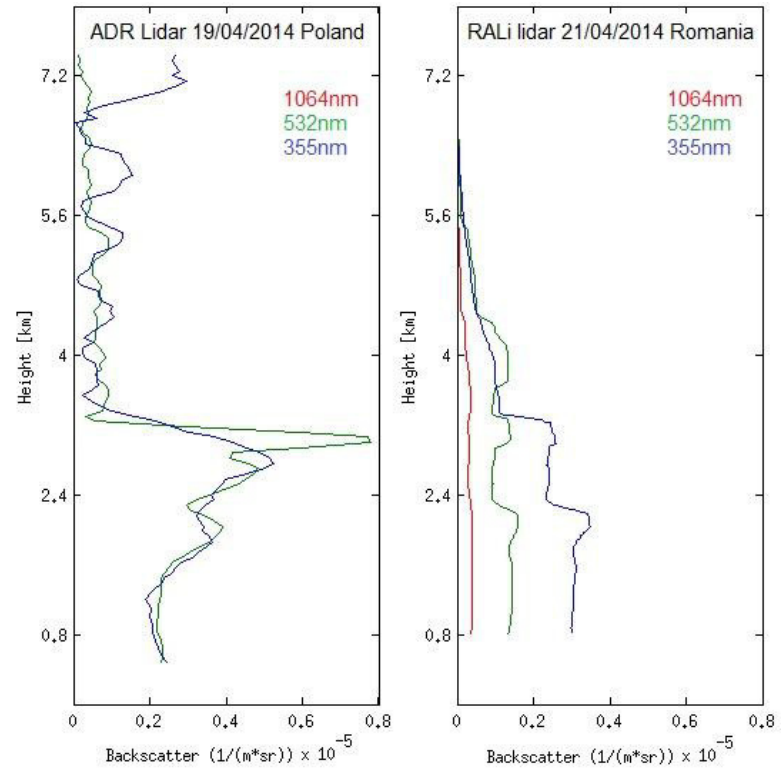

Figure 2. Backscatter coefficient profiles obtained by Raman method from 21 to 22 UTC on 19/07/2014 over Warsaw (left) and from 18:50 to 19:50 UTC on 21/07/2014 over Magurele (right).

The modificanion af the air mass can be followed by investigating the CHM15k ceilometer retrievals at $1064 \mathrm{~nm}$ over Strzyżów (quicklooks are available online at www.polandaod.pl), that show structures of enhanced aerosol load at an altitude of about $1 \mathrm{~km}$ between 19 UTC on July $19^{\text {th }}, 2014$ and 5 UTC on July $20^{\text {th }}, 2014$.

The backward trajectories (Fig. 1) indicate that the air located at the lower heights (between 1 and 1.5 $\mathrm{km}$ ) over Magurele on July $21^{\text {st }}, 2014$ was roughly at about $4 \mathrm{~km}$ over Warsaw 2 days earlier. The aerosol layer present over Warsaw at height about $3 \mathrm{~km}$ for $532 \mathrm{~nm}$ and those present between 2-2.7 $\mathrm{km}$ for $532 \mathrm{~nm}$ and $355 \mathrm{~nm}$ (Fig.2) was likely modified by Carpathian Mountains prior to its arrival at Magurele, since it is not showing the same characteristics over Magurele which it had over Warsaw. The second air-mass of interest, i.e. a well defined layer detected at about $4 \mathrm{~km}$ over Magurele on July $21^{\text {st }}, 2014$ was directly transported at that altitude from Morocco (Fig.1). Thus it is likely that it contained the mineral dust particles that originated form Saharan Desert, what is also confirmed by enhanced linear depolarization ratio of $24 \%$ (not shown here) obtained by RALi at this altitude. The backscatter over Magurele for the layer at $4 \mathrm{~km}$ is of about $0.3 \cdot 10^{-6}$ at $1064 \mathrm{~nm}, 1.3 \cdot 10^{-6}$ at $532 \mathrm{~nm}$ and 
$0.9 \cdot 10^{-6} \mathrm{~m}^{-1} \mathrm{sr}^{-1}$ at $355 \mathrm{~nm}$, that indicates the dust particles were aged.

\section{CONCLUSIONS}

Meridional air-flow, coming from Warsaw to Magurele, is the point of interest in this study. The results have been interpreted on basis of longrange aerosol transport analysis and lidar derived backscatter coefficients and depolarization ratios measured over Warsaw and Magurele. Based on the optical properties derived from the lidar signals at the two sites we are able to assess the air-mass modification between 2 days period and analyze the role of Carpathian Mountains. In this case study is shown how the air arriving to Magurele at height about $1.5 \mathrm{~km}$, coming from high altitudes $>4.5 \mathrm{~km}$ over north-western Poland, has changed its characteristics along the way. Moreover, a dust layer coming from Africa has been identified over Magurele, showing the typical depolarization characteristics for such aerosol type [6].

\section{ACKNOWLEDGEMENT}

We want to acknowledge Aerosols, Clouds, and Trace gases Research Infrastructure Network (ACTRIS) for the Trans National Access (TNA) training activity we were able to perform at RADO installations in December 2014.

The Polish lidar development was financed by FNITP, Poland (Grant No.519/FNITP/115/2010).

This work has been partially supported by the Romanian Programme STAR-ESA Project No.39/2012- SIAFIM

We acknowledge the NOAA Air Resources Laboratory (ARL) for the provision of the HYSPLIT transport model (http://www.arl.noaa.gov/ready.php) used for the interpretation for the results obtained in this publication.

\section{REFERENCES}

[1] Pappalardo, et al., 2014: EARLINET towards an advanced sustainable European aerosol lidar network, Atmos. Meas. Tech., 7, 2389-2409.
[2] Nemuc, A., I.S. Stachlewska, J. Vasilescu, A. Gorska, D. Nicolae, and C. Talianu, 2014: Optical properties of long-range transported volcanic ash over Romania and Poland during Eyjafjallajökull eruption in 2010, Acta Geophys., 62(2), 350-366.

[3] Janicka, L., I.S. Stachlewska, K.M. Markowicz, H. Baars, R. Engelmann, and B. Heese, 2015: Lidar measurements of Canadian forest fire smoke episode observed in July 2013 over Warsaw, Poland, International Laser Radar Conference (ILRC 27th), 5-10 July 20215, New York, USA, Paper ID: 246.

[4] Althausen, D., R. Engelmann, H. Baars, B. Heese, A. Ansmann, D. Müller, M. Komppula, 2009: Portable Raman Lidar PollyXT for Automated Profiling of Aerosol Backscatter, Extinction, and Depolarization. J. Atmos. Oceanic Technol., 47, 2366-2378.

[5] Ansmann A., Riebesell M., and C. Weitkamp, 1990: Measurement of atmospheric aerosol extinction profiles with a Raman lidar, Opt. Lett., 15(13), 746-748.

[6] Freudenthaler, V., et al., 2009: Depolarization ratio profiling at several wavelengths in pure Saharan dust during SAMUM 2006, Tellus B, 61(1), 165-179.

[7] Veselovskii, I., et al., 2002: Inversion with regularization for the retrieval of tropospheric aerosol parameters from multiwavelength lidar sounding, Appl Optics 41(18), 3685-3699.

[8] Stachlewska I.S., Piądłowski M., Migacz S., Szkop A., Zielińska A.J, and Swaczyna P.L., 2012; Ceilometer observations of the boundary layer over Warsaw, Poland, Acta Geophys. 60(5), 1386-1412.

[9] Sokół P., I.S. Stachlewska I. Ungureanu, S. Stefan, 2013: Evaluation of the Boundary Layer Morning Transition Using the CL-31 Ceilometer Signals. Acta Geophys., 60(2), 367-380.

[10] Costa-Surós M., J. Calbó, J.A. González, and J. Martin-Vide, 2014: Behavior of cloud base height from ceilometer measurements. Atmos. Res., 127, 64-76. 